\title{
Factors influencing cerebrospinal fluid and plasma HIV-I RNA detection rate in patients with and without opportunistic neurological disease during the HAART era
}

\author{
Paulo P Christo*1,3, Dirceu B Greco ${ }^{2}$, Agdemir W Aleixo ${ }^{2}$ and \\ Jose A Livramento ${ }^{3}$
}

Address: ${ }^{1}$ Eduardo de Menezes Hospital, FHEMIG, Belo Horizonte, MG, Brasil, ${ }^{2}$ Department of Infectious Diseases, Federal University of Minas Gerais, Brasil and ${ }^{3}$ Department of Neurology, University of São Paulo, Brasil

Email: Paulo P Christo* - ppc@gold.com.br; Dirceu B Greco - greco@medicina.ufmg.br; Agdemir W Aleixo - agdemir@medicina.ufmg.br; Jose A Livramento - lsflcr@terra.com.br

* Corresponding author

Published: 2I December 2007

BMC Infectious Diseases 2007, 7:147 doi:10.1/86/147/-2334-7-147

This article is available from: http://www.biomedcentral.com/I47/-2334/7//47

(C) 2007 Christo et al; licensee BioMed Central Ltd.

This is an Open Access article distributed under the terms of the Creative Commons Attribution License (http://creativecommons.org/licenses/by/2.0), which permits unrestricted use, distribution, and reproduction in any medium, provided the original work is properly cited.

\begin{abstract}
Background: In the central nervous system, HIV replication can occur relatively independent of systemic infection, and intrathecal replication of HIV-I has been observed in patients with HIV-related and opportunistic neurological diseases. The clinical usefulness of HIV-I RNA detection in the cerebrospinal fluid (CSF) of patients with opportunistic neurological diseases, or the effect of opportunistic diseases on CSF HIV levels in patients under HAART has not been well defined. We quantified CSF and plasma viral load in HIV-infected patients with and without different active opportunistic neurological diseases, determined the characteristics that led to a higher detection rate of HIV RNA in CSF, and compared these two compartments.
\end{abstract}

Methods: A prospective study was conducted on $90 \mathrm{HIV}$-infected patients submitted to lumbar puncture as part of a work-up for suspected neurological disease. Seventy-one patients had active neurological diseases while the remaining 19 did not.

Results: HIV-I RNA was quantified in 90 CSF and 70 plasma samples. The HIV-I RNA detection rate in CSF was higher in patients with neurological diseases, in those with a CD4 count lower than $200 \mathrm{cells} / \mathrm{mm}^{3}$, and in those not receiving antiretroviral therapy, as well as in patients with detectable plasma HIV-I RNA. Median viral load was lower in CSF than in plasma in the total population, in patients without neurological diseases, and in patients with toxoplasmic encephalitis, while no significant difference between the two compartments was observed for patients with cryptococcal meningitis and HIV-associated dementia. CSF viral load was lower in patients with cryptococcal meningitis and neurotoxoplasmosis under HAART than in those not receiving HAART.

Conclusion: Detection of HIV-I RNA in CSF was more frequent in patients with neurological disease, a CD4 count lower than 200 cells $/ \mathrm{mm}^{3}$ and detectable plasma HIV-I. Median HIV-I RNA levels were generally lower in CSF than in plasma but some patients showed higher CSF levels, and no difference between these two compartments was observed in patients with cryptococcal meningitis and HIV-associated dementia, suggesting the presence of intrathecal viral replication in these patients. HAART played a role in the control of CSF HIV levels even in patients with cryptococcal meningitis and neurotoxoplasmosis in whom viral replication is potentially higher. 


\section{Background}

The assessment of plasma viral load has led to revolutionary advances in the understanding of viral dynamics in the HIV-infected organism and has become one of the most important tools for monitoring the response to antiretroviral (ARV) therapy [1-4]. Highly active antiretroviral therapy (HAART) has brought a real chance of effectively controlling the infection, with high suppression of plasma viral load and improvement of the cellular immune response, thus reducing mortality and the incidence of new opportunistic infections and HIV-associated dementia (HIV-D) [5-11]. However, opportunistic neurological diseases continue to occur, especially in developing countries. In Brazil, despite a public health system that provides ARV drugs free of charge, this disease continues to occur due to irregular immunovirological monitoring and late diagnosis of the infection [12].

Evidence indicates that in different compartments of the body such as the central nervous system, HIV replication can occur relatively independent of systemic infection [13-18], and intrathecal replication of HIV-1 has been observed in patients with HIV-related and opportunistic neurological diseases. In contrast to plasma viral load, the usefulness and predictive value of the analysis of cerebrospinal fluid (CSF) viral load are less clear $[19,20]$.

The clinical usefulness of HIV-1 RNA detection in the CSF of patients with opportunistic neurological diseases, or the effect of opportunistic diseases on CSF HIV levels in patients under HAART has not been well defined. Many studies regarding CSF viral load have been conducted in developed countries on patients with HIV-related neurological disease; however, few studies have been carried out in developing countries and on patients with opportunistic disease.

The objectives of the present study were to compare HIV RNA levels in CSF and plasma of HIV-infected patients with toxoplasmic encephalitis, cryptococcal meningitis, HIV-D and without active neurological diseases, as well as to determine the characteristics that led to a higher detection rate of HIV RNA in CSF and the influence of HAART on CSF viral load.

\section{Methods}

We prospectively evaluated $90 \mathrm{HIV}$-infected patients who were submitted to lumbar puncture between May 2002 and May 2003 as part of the work-up for a suspicion of neurological disease at a public AIDS Reference Hospital (Eduardo Menezes Hospital, FHEMIG), Belo Horizonte, Brazil. The study was approved by the Research Ethics Committee of the institution and written informed consent was obtained from all participants.
Data collected from each patient included gender, age, CD4+ lymphocyte count, use of ARV therapy, duration of ARV therapy, and presence and type of neurological disease.

Neurological diseases were diagnosed based on the following criteria: criteria of the Working Group of the American Academy of Neurology Task Force [21] for the diagnosis of HIV-D and vacuolar myelopathy, a suggestive skull computed tomography scan and a clinical and tomographic image response to specific drug treatment for the diagnosis of toxoplasmosis, and a positive India ink result, a specific cryptococcal antigen test or positive CSF culture for the diagnosis of cryptococcal meningitis. Tuberculous meningitis was diagnosed based on clinicalneurological signs of lymphocytic meningitis and the presence of alcohol-acid resistant bacilli or a positive CSF culture. Stereotactic biopsies were obtained for the diagnosis of progressive multifocal leukoencephalopathy (PML) and bacterial abscess. An undetermined diagnosis was considered when the patients showed neurological syndromes characterized by meningitis, encephalitis or expansive intracranial lesions and when no etiology could be established after work-up.

CSF samples from all 90 patients were submitted to the quantification of HIV-1 RNA and the virus was also quantified in plasma in 70 of them. Twenty patients didn't have a plasma sample collected or samples were collected 48 hours after the CSF samples, so they were excluded from the analysis.

CSF and plasma samples were collected within an interval of 48 hours between each other and stored at $-70^{\circ} \mathrm{C}$ until the time of processing within a maximum period of 6 months. HIV-1 RNA was quantified by NASBA using 1.0 $\mathrm{ml}$ centrifuged plasma and $0.1 \mathrm{ml}$ not centrifuged CSF according to manufacturer instructions (Nuclisens HIV-1 QT, Organon TeKniKa, Boxtel, Netherlands), with a sensitivity of 80 copies $/ \mathrm{ml}\left(1.90 \log _{10}\right.$ copies $\left./ \mathrm{ml}\right)$. None of the CSF samples contained more than 10 red cells $/ \mathrm{mm}^{3}$.

\section{Statistical analysis}

Individual associations of the variables $\mathrm{CD} 4 \mathrm{~T}$ lymphocyte count, use of ARV therapy, presence of neurological disease and detectable plasma HIV-1 RNA with the detection of HIV-1 RNA in CSF were determined by the chi-square test. Multivariate logistic regression analysis was used to evaluate the overall effect of these four variables. The nonparametric Wilcoxon test was used for comparison of CSF and plasma viral load. The nonparametric Mann-Whitney test was applied to the comparison of CSF viral load in patients with and without ARV therapy. The level of significance was set at $5 \%$ for all tests. 
A $\log 10$ transformation was performed on all HIV-1 RNA concentration values (copies per milliliter). For patients with undetectable HIV-1 RNA, a log-scale value of 0 was assigned to avoid the problem of expressing zero logarithmically. All statistical analyses were performed with the SPSS 8.0 program (SPSS Inc.).

\section{Results Characteristics of the population}

Table 1 summarizes the clinical and laboratory characteristics of the 90 patients. The median CD4+ Tymphocyte count was 89 cells $/ \mathrm{mm}^{3}$ and no differences in median CD4 count were observed between patients with different types of neurological diseases or between those undergoing ARV therapy or not. Forty-nine (54.4\%) of the 90 patients used ARV drugs, all in the HAART regimen.

Seventy-one $(78.9 \%)$ of the 90 patients presented with neurological diseases, while the remaining 19 patients $(21.1 \%)$ did not have active opportunistic or AIDS-related neurological diseases and no clinical or laboratory evidence of active infection was observed in these patients.

\section{Detection rate of HIV RNA in CSF}

HIV-1 RNA was detected in $62.2 \%$ of the 70 plasma samples and in $55.6 \%$ of the 90 CSF samples analyzed. The

Table I: Characteristics of the 90 subjects studied

\begin{tabular}{ll}
\hline Mean age [years (range)] & $36(20-60)$ \\
Sex (n) & 65 \\
Male & 25 \\
Female & \\
CD4-positive cells (cells $\left./ \mathrm{mm}^{3}\right)$ & 149 \\
Mean & 89 \\
Median & $1-405$ \\
Range & $24(0.5-108)$ \\
Mean time since diagnosis [month (range)] & \\
Pre-existing ARV therapy (n) & 49 \\
Yes & 40 \\
No & $10(0.3-60)$ \\
Mean duration of ARV therapy [month (range)] & 19 \\
Neurologically asymptomatic (n) & 71 \\
Neurologically symptomatic (n) & 6 \\
HIV-associated dementia & 1 \\
Vacuolar myelopathy & \\
Opportunistic CNS infections (43) & 19 \\
Toxoplasmosis & 15 \\
Cryptococcal meningitis & 3 \\
Tuberculosis meningitis & 2 \\
PML & \\
Associations &
\end{tabular}

ARV, antiretroviral drug; CNS, central nervous system; PML, progressive multifocal leukoencephalopathy detection rate of RNA HIV-1 in CSF was higher in patients with neurological diseases $(63.4 \%)$, in patients with a CD4+ T cell count lower than 200 cells $/ \mathrm{mm}^{3}(64.4 \%)$, in patients not undergoing ARV therapy (82.5\%), and in patients with detectable plasma HIV-1 RNA (71.4\%). However, after multivariate analysis the use of ARV was no longer significant in the detection of HIV-1 RNA in CSF (Table 2).

\section{Viral load in CSF and plasma of the $\mathbf{7 0}$ subjects}

Median viral load was lower in CSF than in plasma in the total population $(p<0.001)$, in patients without neurological diseases $(\mathrm{p}=0.012)$, and in patients with toxoplasmic encephalitis $(\mathrm{p}=0.013)$ (Table 3$)$. In the patients with toxoplasmic encephalitis, there was a difference between CSF and plasma viral load, but just in the patients that didn't use therapy. There weren't any differences in the patients that used therapy (Figure 1). On the other hand, no significant difference between the two compartments was observed in patients with cryptococcal meningitis $(\mathrm{p}=0.209)$ and HIV-D $(\mathrm{p}=0.273)$ and this occurred in patients that did or didn't use therapy (Figures 2 and 3). Concerning the patients that didn't have neurological disease, there was a difference of viral load between compartments in just the patients that used therapy $(\mathrm{p}=0,043)$ (Figure 4).

In absolute values, the median plasma and CSF viral load ratio was approximately $28: 1$, and this ratio was lower in patients with neurological diseases (12 times) and higher in patients without neurological diseases (335 times). The lowest ratio was observed in patients with cryptococcal meningitis (3.4 times) and HIV-D (3 times). Twelve $(17 \%)$ of the 70 patients for whom concomitant CSF and plasma samples were available showed higher absolute values in CSF than in plasma, with 11 of them having opportunistic disease of the central nervous system and HIV-D. The mean and median number of cells in CSF was higher in these patients than in the total population.

Median CSF and plasma viral load were significantly lower in patients with opportunistic diseases in general, cryptococcal meningitis and neurotoxoplasmosis under HAART. Among the 35 patients with opportunistic neurological diseases in whom HIV-1 RNA was detected in CSF, 20 received HAART (median of $<1.9 \log _{10}$ copies $/ \mathrm{ml}$ ) and 15 did not (median of $3.76 \log _{10}$ ). In plasma, the median was $2.82 \log _{10}$ copies/ml for patients receiving HAART and $4.57 \log _{10}$ copies/ml for those who did not.

\section{Discussion \\ Detection rate of HIV-I RNA in CSF}

In the present study, the detection rate of the virus in CSF (56\%) and plasma (62\%) was lower than those reported in other investigations. One possible explanation is that 
Table 2: Frequency of HIV-I RNA detection in CSF according to the clinical and laboratory characteristics of the patients

\begin{tabular}{|c|c|c|c|c|c|c|}
\hline \multirow[t]{2}{*}{ Characteristic } & \multirow[t]{2}{*}{ Presence (n) } & \multicolumn{2}{|c|}{ CSF HIV-I RNA } & \multirow[t]{2}{*}{$\mathrm{P}$ (univariate) $^{\mathrm{b}}$} & \multirow[t]{2}{*}{$\mathrm{P}$ (multivariate) ${ }^{\mathrm{c}}$} & \multirow[t]{2}{*}{ OR } \\
\hline & & $>80(\%)^{\mathrm{a}}$ & $<80(\%)$ & & & \\
\hline \multirow[t]{2}{*}{ Disease $^{d}$} & Yes (7I) & 63.4 & 36.6 & $<0.001$ & 0.0010 & 22.1 \\
\hline & No (19) & 26.3 & 73.7 & & & \\
\hline \multirow[t]{2}{*}{ CD4 } & $<200(17)$ & 64.4 & 35.6 & $<0.001$ & 0.0021 & 18.7 \\
\hline & $>200(73)$ & 17.6 & 82.4 & & & \\
\hline \multirow[t]{2}{*}{ ARV use } & No (40) & 82.5 & 17.5 & $<0.001$ & NS & $*$ \\
\hline & Yes (49) & 34.7 & 65.3 & & & \\
\hline \multirow[t]{2}{*}{ Plasma viral load } & $>80(56)^{\mathrm{a}}$ & 71.4 & 28.6 & $<0.001$ & 0.0008 & 22.6 \\
\hline & $<80(\mid 4)$ & 14.3 & 85.7 & & & \\
\hline
\end{tabular}

aDetection limit: 80 copies/ml; bchi-square test; cmultivariate logistic regression analysis; dneurological disease; ARV, antiretroviral drug; NS, not significant; OR, odds ratio.

$54 \%$ of our patients were on HAART and $21 \%$ of the patients did not have HIV-related or secondary neurological diseases, with neurological diseases being known to increase viral replication in CSF and plasma and the consequent detection of the virus [22-25].

Qualitative studies using PCR have shown that HIV can be detected in CSF at frequencies ranging from 64\% [26] to $90 \%$ [27]. A variable frequency has also been reported in other studies using quantitative detection methods depending on patient characteristics, with frequencies ranging from $66 \%[23,28,29]$ to $98 \%$ of CSF samples. The latter rate was reported by Gisslen et al.[30] for patients not undergoing ARV therapy who used a more sensitive PCR kit with a detection limit of 20 copies per ml.

Studies regarding HIV-1 RNA detection in CSF should be analyzed with caution. First, quantitative methods have been shown to be less sensitive than qualitative methods [31]. Second, some studies showing a higher detection rate of HIV-1 RNA in CSF were performed before 1998, when most patients were not on HAART. Third, the groups of patients analyzed in these studies differ in terms of clinical characteristics such as time since infection,

Table 3: Median viral load in CSF and plasma of 70 patients with and without neurological disease

\begin{tabular}{|c|c|c|c|}
\hline \multirow[t]{2}{*}{ Patient group } & \multicolumn{2}{|c|}{ Copies/ml (median) } & \multirow[b]{2}{*}{$\mathbf{p}^{\mathbf{a}}$} \\
\hline & Plasma & CSF & \\
\hline \multicolumn{4}{|c|}{ Total population $(n=70)$} \\
\hline VL (absolute values) & 19,200 & 695 & \\
\hline $\log _{10}$ & 4.28 & 2.81 & $<0.001$ \\
\hline \multicolumn{4}{|c|}{ Neurological disease $(n=58)$} \\
\hline VL (absolute values) & 22,200 & 1,850 & \\
\hline $\log _{10}$ & 4.35 & 3.27 & $<0.001$ \\
\hline \multicolumn{4}{|c|}{ Without neurological disease $(n=12)$} \\
\hline VL (absolute values) & 335 & 1 & \\
\hline $\log _{10}$ & 2.45 & $<1.9$ & 0.012 \\
\hline \multicolumn{4}{|c|}{ Neurotoxoplasmosis (16) } \\
\hline VL (absolute values) & 27,500 & 3,200 & \\
\hline $\log _{10}$ & 4.44 & 3.45 & 0.013 \\
\hline \multicolumn{4}{|c|}{ Cryptococcal meningitis $(n=12)$} \\
\hline VL (absolute values) & 16.500 & 4.900 & \\
\hline $\log _{10}$ & 4.22 & 3.70 & 0.209 \\
\hline \multicolumn{4}{|c|}{ Undetermined diseases $(n=13)$} \\
\hline VL (absolute values) & 120,000 & 17,000 & \\
\hline $\log _{10}$ & 5.08 & 4.23 & 0.028 \\
\hline \multicolumn{4}{|l|}{ HIV-D $(n=6)$} \\
\hline VL (absolute values) & 2,641 & 910 & \\
\hline $\log _{10}$ & 2.82 & 2.89 & 0.273 \\
\hline
\end{tabular}

a nonparametric Wilcoxon test; VL, viral load; HIV-D; HIV-associated dementia. 


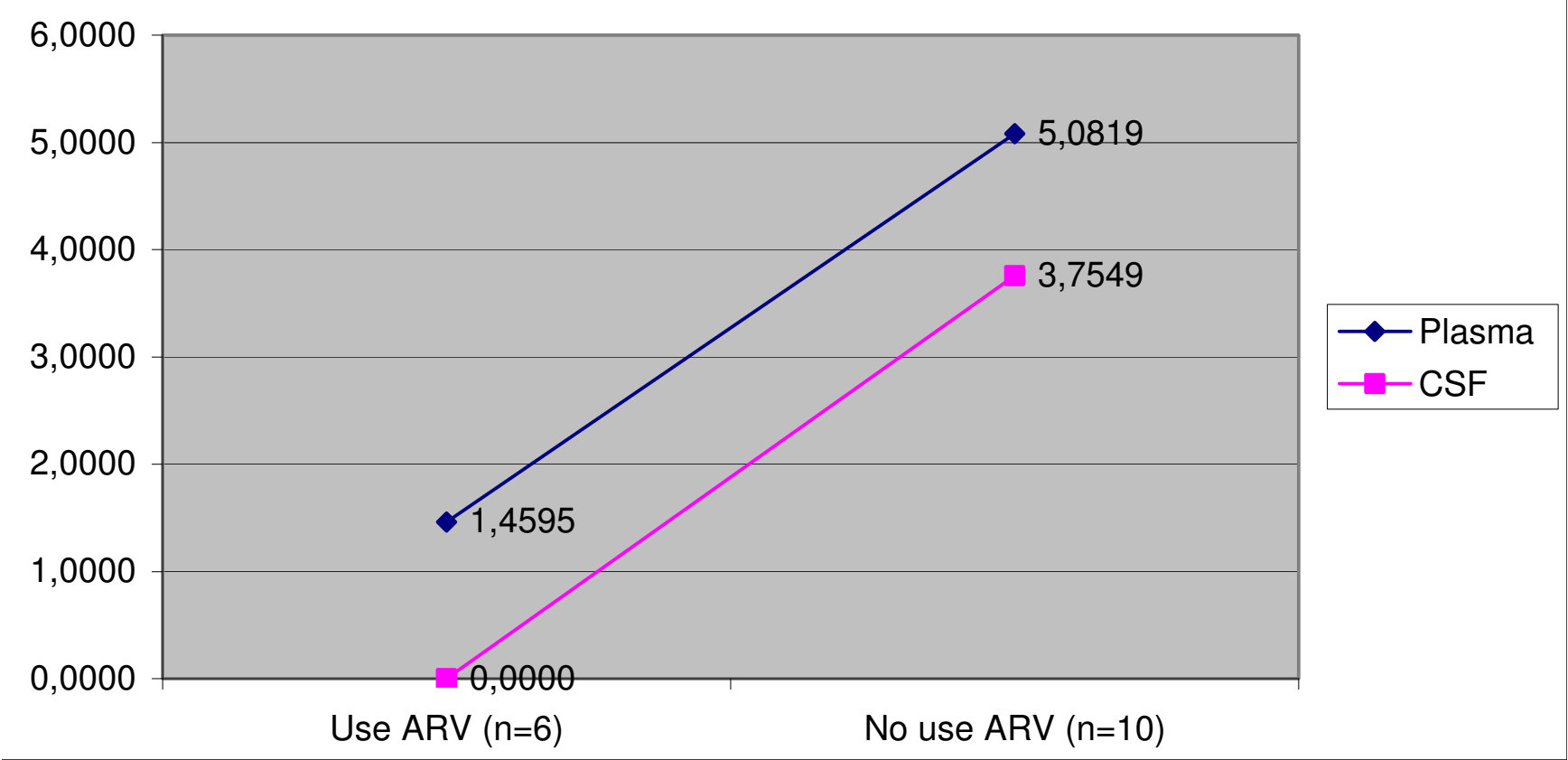

\section{Figure I}

Median viral load CSF and plasma in the patients with toxoplasmic encephalitis according to antiretroviral therapy.

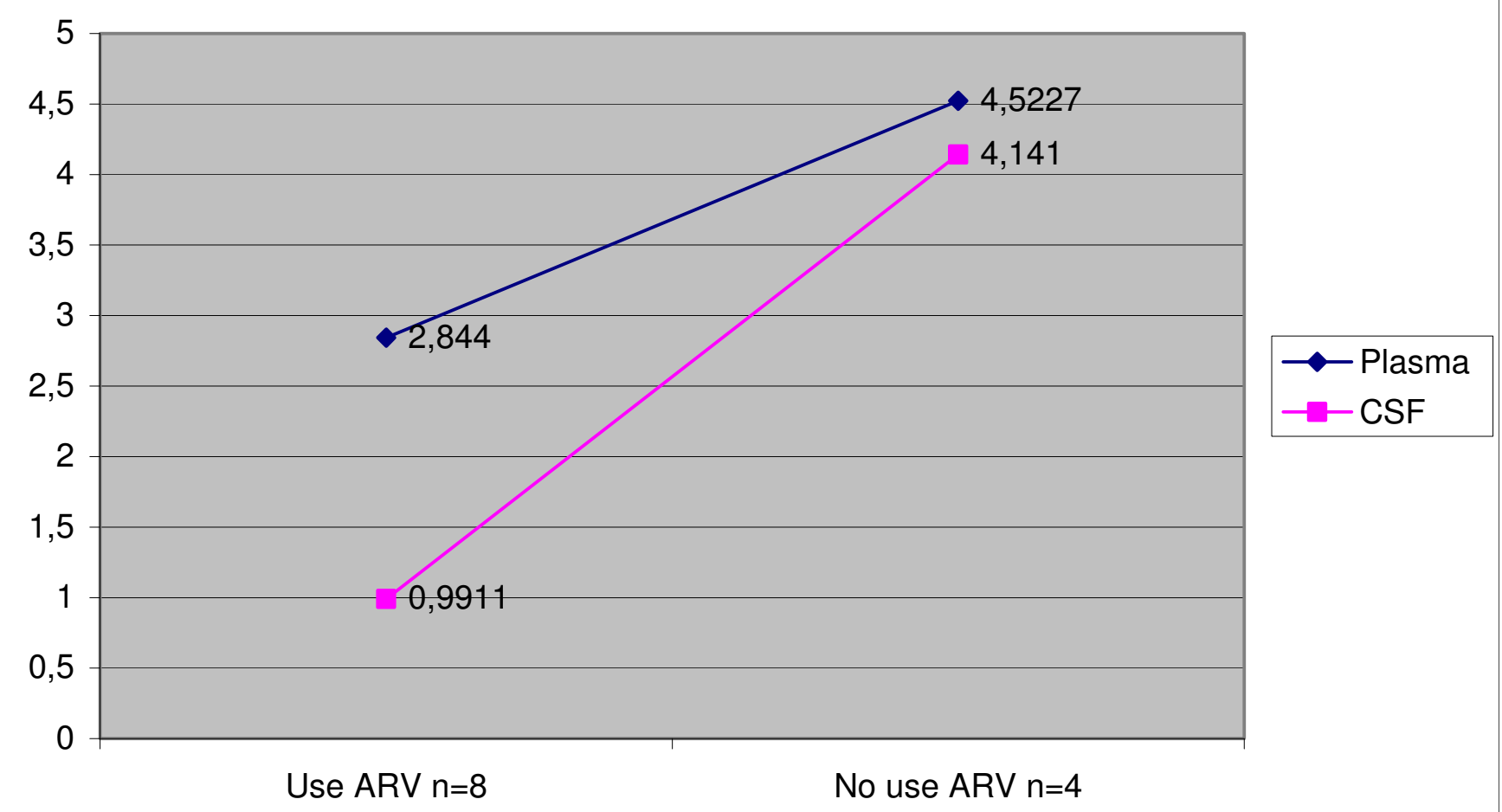

\section{Figure 2}

Median viral load CSF and plasma in the patients with cryptococcal meningitis according to antiretroviral therapy. 


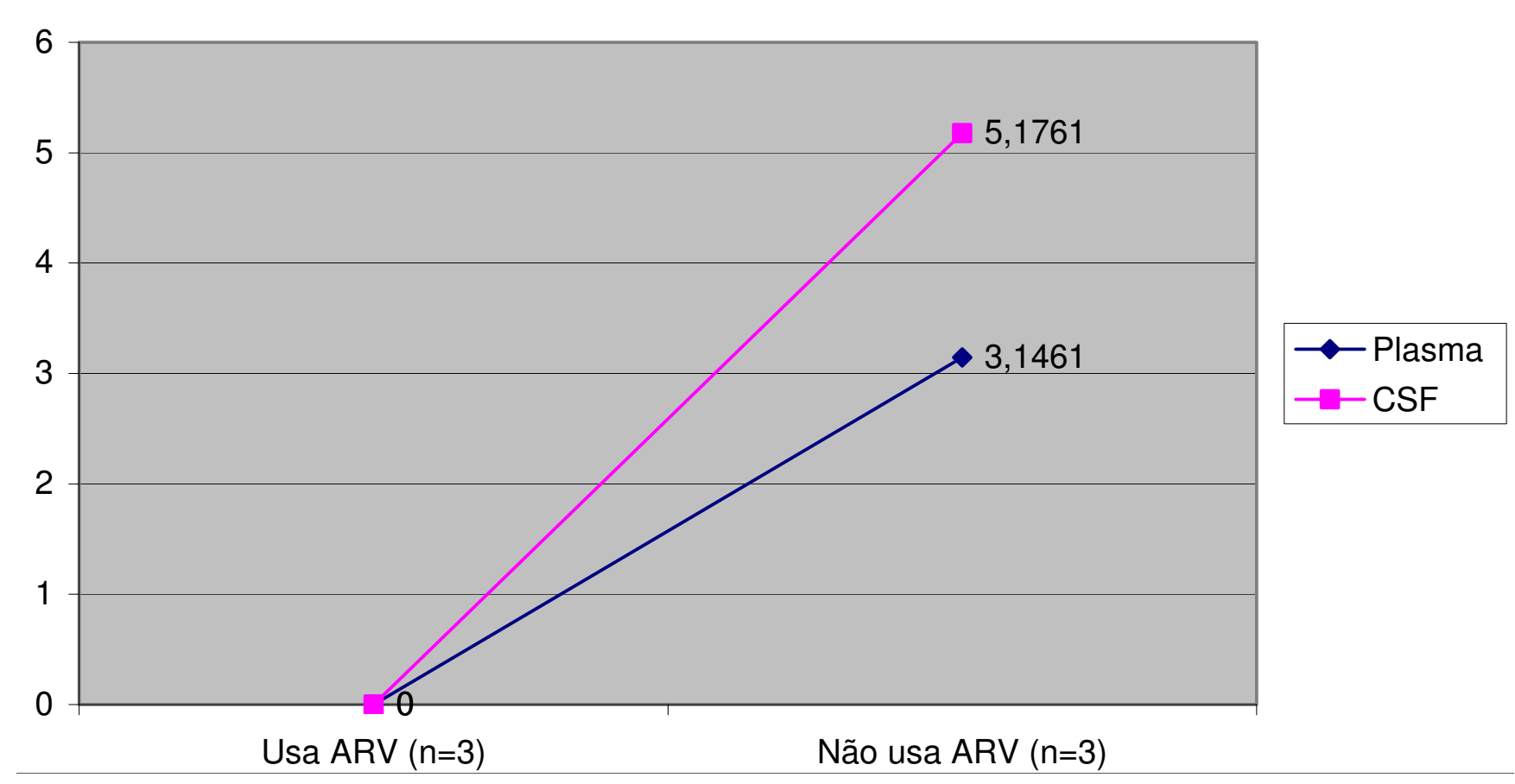

Figure 3

Median viral load CSF and plasma in the patients with Dementia-HIV according to antiretroviral therapy.

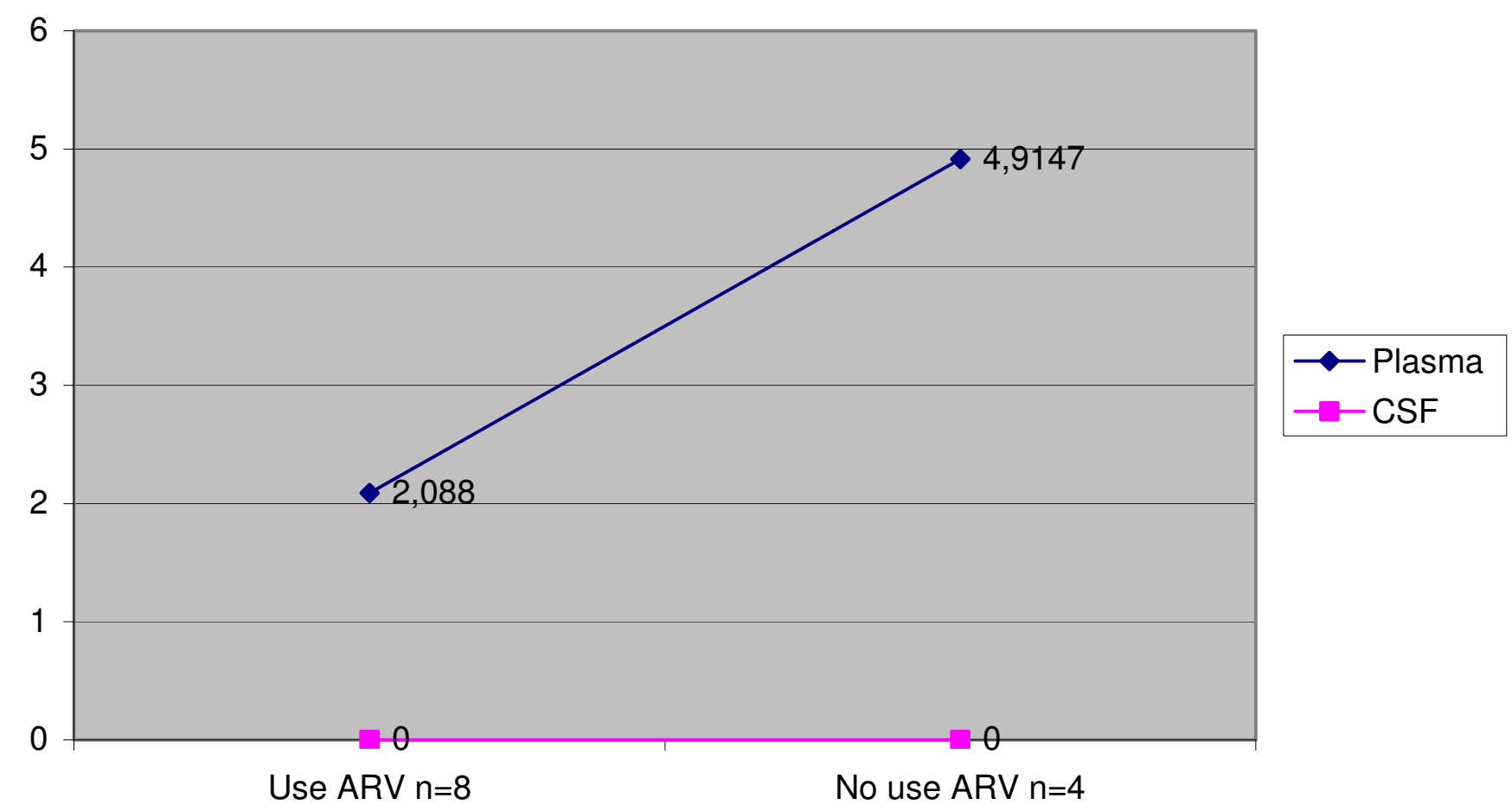

\section{Figure 4}

Median viral load CSF and plasma in the patients with no neurological disease. according to antiretroviral therapy. 
presence of HIV-related or secondary neurological disease, or absence of symptoms. Finally, in the case of quantitative methods, the sensitivity of the method used might influence the detection rate of HIV-1 in CSF.

Detection of HIV-1 RNA in CSF varied according to the characteristics of the population and was higher in patients with a CD4 count lower than 200 cells $/ \mathrm{mm}^{3}$, patients with neurological disease, patient not using ARV drugs, and patients with detectable plasma HIV-1 RNA, but use of ARV therapy was no longer significant upon multivariate analysis.

The chance of detecting HIV-1 RNA in CSF of patients with neurological diseases was approximately 22 times higher than in patients without neurological diseases. In patients with a CD4 count lower than 200 cells $/ \mathrm{mm}^{3}$ the chance was almost 19 times higher when compared to patient with a CD4 count higher than 200 cells $/ \mathrm{mm}^{3}$, and a 23 times higher chance of detecting HIV-1 RNA in CSF was observed in patients with detectable plasma viral load.

The unfavorable effect of neurological diseases on CSF HIV levels has also been shown to be independent of ARV therapy and may depend both on the increased permeability of the blood-brain barrier, associated with enhanced trafficking of infected cells and cytokines during neurological disease, and on the increased local production of HIV1 despite systemic antiviral control [15]. However, median CSF viral load was lower in patients with cryptococcal meningitis and neurotoxoplasmosis receiving HAART than in those with cryptococcal meningitis and neurotoxoplasmosis who did not use HAART, demonstrating that HAART plays a certain role in the control of CSF viral load in these patients with potential intrathecal viral replication.

HIV-1 RNA levels in CSF have been shown to be correlated with opportunistic neurological diseases [24,25] and HIV-D [22], and HIV-1 RNA is more easily detected in patients not undergoing HAART $[15,32]$. HAART has been shown to be effective in reducing viral replication in both plasma and CSF [15,33-35].

\section{Viral load in CSF and plasma}

Significant differences in median viral load between the two compartments (plasma and CSF) were also observed in the total population studied and in patients with and without neurological diseases, but there was no difference when individuals with cryptococcal meningitis and HIV$\mathrm{D}$ were considered separately and this occurred in patients that did or didn't use therapy. The ratio between median plasma and CSF viral load was lower in these patients, showing that HIV-1 RNA levels increased in the two com- partments, but the increase was more significant in CSF, probably due to intrathecal replication of HIV-1 or to increased passage of the virus through the blood-brain barrier in these patients. The difference between CSF and plasma viral load is considered to be an independent sign of viral replication in the cerebral compartment $[36,37]$.

In absolute values, the median viral load was 28 times higher in plasma than in CSF, but in $12(17 \%)$ of the 70 patients for whom concomitant CSF and plasma viral loads were available, HIV levels were higher in CSF than in plasma. These findings are similar to reports in the literature showing that median or mean plasma levels are usually higher than the corresponding concentrations in CSF, but CSF viral load can be higher in individual patients $[25,29,33,38-42]$. CSF HIV-1 RNA levels are often relatively low, approximately 1 log lower than plasma levels [43]. The finding that $17 \%$ of the patients had a higher viral load in CSF than in plasma supports the theory that HIV levels in CSF do not merely reflect plasma HIV levels.

\section{Conclusion}

Detection of HIV-1 RNA in CSF was directly related to the characteristics of the patients such as the presence of neurological disease, a CD4 count lower than 200 cells $/ \mathrm{mm}^{3}$, and detectable plasma HIV-1 RNA. Median HIV-1 RNA levels were generally lower in CSF than in plasma but some patients showed higher CSF levels, and no difference between these two compartments was observed in patients with cryptococcal meningitis and HIV-D, suggesting the presence of intrathecal viral replication in these patients. HAART played a role in the control of CSF HIV levels even in patients with cryptococcal meningitis and neurotoxoplasmosis in whom viral replication is potentially higher.

\section{Competing interests}

The author(s) declare that they have no competing interests.

\section{Authors' contributions}

PC participated with subject evaluations and planning and participated in analysis, interpretation of the data and in the study planning. JL helped in the study planning and draft the manuscript, participated in analysis. AA participated in analysis and coordinated the viral load assays. DG helped in the study planning and draft the manuscript, participated in analysis.

\section{Acknowledgements}

We would like to thank Dr. Carlos Mauricio Antunes de Figueiredo for revising English text and helping with the statistical analysis. Aleida Nazareth Soares for doing the statistical analysis in the computer program and helping to interpret it. 


\section{References}

I. Powderly WG: Current approaches to treatment for HIV-I infection. J Neurovirol 2000, 6(suppl I):S8-SI3.

2. Piatak M Jr, Saag MS, Yang LC, Clark SJ, Kappes JC, Luk KC, Hahn BH, Shaw GM, Lifson JD: High levels of HIV-I in plasma during all stages of infection determined by competitive PCR. Science 1993, 259: |749-I754.

3. Perelson AS, Neumann AU, Markowitz M, Leonard JM, Ho DD: HIVI dynamics in vivo: virion clearance rate, infected cell lifespan, and viral generation time. Science 1996, 27I:1582-I86.

4. Mellors JW, Munoz A, Giorgi JV, Margolick JB, Tassoni CJ, Gupta P, Kingsley LA, Todd JA, Saah AJ, Detels R, Phair JP, Rinaldo CR Jr: Plasma viral load and CD4 + lymphocytes as prognostic markers of HIV-I infection. Ann Intern Med 1997, I 26:946-954.

5. Brodt HR, Kamps BS, Gute P, Knupp B, Staszewski S, Helm EB: Changing incidence of AIDS-defining illnesses in the era of antiretroviral combination therapy. AIDS 1997, I I:I73 I-I738.

6. Lambotte O, Kumaran D, Tardieu M: HIV-I persistence, viral reservoir, and the central nervous system in the HAART era. Brain Pathol 2003, I 3:95-103.

7. Albright AV, Samantha SS, González-Scarano F: Pathogenesis of human immunodeficiency virus-induced neurological disease. J Neurovirol 2003, 9:222-227.

8. Sacktor N, McDermott MP, Marder K, Schifitto G, Selnes OA McArthur JC, Stern Y, Albert S, Palumbo D, Kieburtz K, De Marcaida JA, Cohen B, Epstein L: HIV-associated cognitive impairment before and after the advent of combination therapy. I Neurovirol 2002, 8(2): I 36- | 42

9. Neuenburg JK, Brodt HR, Herndier BG, Bickel M, Bacchetti P, Price RW, Grant RM, Schlote W: HIV-I related neuropathology, I 985 to 1999: rising prevalence of HIV encephalopathy in the era of highly active antiretroviral therapy. I Acquir Immune Defic Syndr 2002, 3 I: I7|-I77.

10. d'Arminio Monforte A, Cinque P, Mocroft A, Goebel FD, Antunes F, Katlama C, Justesen US, Vella S, Kirk O, Lundgren J, EuroSIDA Study Group: Changing incidence of central nervous system disease in the EurosidA cohort. Ann Neurol 2004, 55(3):320-328.

II. Sackor N: The epidemiology of human immunodeficiency virus-associated neurological disease in the era of highly active antiretroviral therapy. J Neurovirol 2002:I I5-12 I.

12. Oliveira JF, Greco DB, Oliveira GC, Christo PP, Guimarãoes MDC Oliveira RC: Neurological disease in HIV-infected patients in the era of highly active antiretroviral treatment: a Brazilian experience. Rev Soc Bras Med Trop 2006, 39(2): |46-I5I.

13. Pialoux G, Fournier S, Moulignier A, A Poveda J-D, Clavel F, Dupont $B$ : Central nervous system as a sanctuary for HIV-I infection despite treatment with zidovudine, lamivudine and indinavir [letter]. AIDS 1997, I I:1302-I303.

14. Schacker T, Collier AC, Hughes J, Shea T, Corey L: Clinical en epidemiologic features of primary HIV infection. Ann Intern Med 1996, I 25:257-264.

15. Antinori A, Giancola ML, Grisetti S, Soldani F, Alba L, Liuzzi G, Amendola A, Capobianchi M, Tozzi V, Perno CF: Factors influencing virological response to antiretroviral drugs in cerebrospinal fluid of advanced HIV-I infected patients. AIDS 2002 | 6:1867-1876.

16. Tambussi G, Gori A, Capiluppi B, Balotta C, Papagno L, Morandini B, Di Pietro M, Ciuffreda D, Saracco A, Lazzarin A: Neurological symptoms during primary human immunodeficiency virus (HIV) infection correlate with high levels of HIV RNA in cerebrospinal fluid. Clin Infect Dis 2000, 30:962-965.

17. Chiodi F, Keys B, Albert J, Hagberg L, Lundeberg J, Uhlen M, Fenyo EM, Norkrans G: Human immunodeficiency virus type I is present in the cerebrospinal fluid of a majority of infected individuals. J Clin Microbiol |992, 30:1768-|77|.

18. Sonnerborg AB, Ehrnst AC, Bergdahl SK, Pehrson PO, Skoldenberg $B R$, Strannegard OO: HIV isolation from cerebrospinal fluid in relation in immunological deficiency and neurological symptoms. AIDS 1988, 2(2):89-93.

19. McArthur JC, Haughey N, Gartner S, Conant K, Pardo C, Nath A, Sacktor N: Human immunodeficiency virus-associated dementia: An evolving disease. J Neurovirol 2003, 9:205-22I.

20. Marra CM, Lockhart D, Zunt JR, Perrin M, Coombs RW, Collier AC: Changes in CSF and plasma HIV-I RNA and cognition after starting potent antiretroviral therapy. Neurology 2003, 60:1388-1390.
21. Working Group of America Academy of Neurology AIDS Task Force: Nomenclature and research case definitions for neurologic manifestations of human immunodeficiency virus-type I(HIV-I) infection. Neurology 199I, 4I:778-785.

22. McArthur JC, McClernon DR, Cronin MF, Nance-Sproson TE, Saah AJ, St Clair M, Lanier ER: Relationship between human immunodeficiency virus-associated dementia and viral in cerebrospinal fluid and brain. Ann Neurol 1997, 42:689-698.

23. Ellis RJ, Hsia K, Spector SA, Nelson JA, Heaton RK, Wallace MR, Abramson I, Atkinson JH, Grant I, McCutchan JA: Cerebrospinal fluid human immunodeficiency virus type I RNA levels are elevated in neurocognitively impaired individuals with acquired immunodeficiency syndrome. Ann Neurol 1997, 42:679-688.

24. Brew BJ, Pemberton L, Cunningham P, Law MG: Levels of human immunodeficiency virus type I RNA in cerebrospinal fluid correlate with AIDS dementia stage. I Infect Dis 1997, I 75:963-966.

25. Morris L, Silber E, Sonnenberg P, Eintracht S, Nyoka S, Lyons SF, Saffer D, Koornhof $H$, Martin DJ: High human immunodeficiency virus type I RNA load in the cerebrospinal fluid of patients with lymphocytic meningitis. J Infect Dis 1998, I 77:473-476.

26. Shaunak S, Albright RE, Klotman ME, Henry SC, Bartlett JA: Hamilton JD. Amplification of HIV-I provirus from cerebrospinal fluid and its correlation with neurologic disease. J Infect Dis 1990, 16 I:1068-1072.

27. Schmid P, Conrad A, Syndulko K, Singer EJ, Handley D, Li X, Tao G, Fahy-Chandon B, Tourtellotte WW: Quantifying HIV-I proviral DNA using the polymerase chain reaction on cerebrospinal fluid and blood of seropositive individuals with and without neurologic abnormalities. I Acquir Immune Defic Syndr 1994, 7:777-788.

28. Martin C, Albert J, Hansson P, Pehrsson P, Link H, Sönnerborg A: Cerebrospinal fluid mononuclear cell counts influence CSF HIV-I RNA levels. J Acquir Immune Defic Syndr Hum Retrovirol 1998, I 7(3):2 |4-219.

29. Bossi P, Dupin N, Coutellier A, Bricaire F, Lubetzki C, Katlama C Calvez V: The level of human immunodeficiency virus (HIV) type I RNA in cerebrospinal fluid as a marker of HIV encephalitis. Clin Infect Dis 1998, 26:1072-1073.

30. Gisslén M, Fuchs D, Svennerholm B, Hagberg L: Cerebrospinal fluid viral load, intrathecal immunoactivation, and cerebrospinal fluid monocytic cell count in HIV-I infection. J Acquir Immune Defic Syndr 1999, 21:271-276.

31. Conrad AJ, Schmid P, Syndulko K, Singer EJ, Nagra RM, Russell Tourtellotte WW: Quantifying HIV-I RNA using the polymerase chain reaction on cerebrospinal fluid and serum of seropositive individuals with and without neurologic abnormalities. J Acquir Immune Defic Syndr Hum Retroviral 1995, I 0(4):425-435.

32. Spearman P, Fiscus SA, Smith RM, Shepard R, Johnson B, Nicotera J, Harris VL, Clough LA, McKinsey J, Haas DW: Comparison of Roche MONITOR and Organon Teknika Nuclisens Assays to quantify human immunodeficiency virus type I RNA in cerebrospinal fluid. J Clin Microbiol 2001, 39:1612-1614.

33. McCoig C, Castrejon MM, Castano E, De Suman O, Baez C, Redondo W, McClernon D, Danehower S, Lanier ER, Richardson C, Keller A, Hetherington S, Saez-Llorens X, Ramilo O: Effect of combination antiretroviral therapy on cerebrospinal fluid HIV RNA, HIV resistance, and clinical manifestations of encephalopathy. J Pediatr 2002, I 4 I ( I):36-44.

34. Cinque $P$, Bestetti A, Morelli $P$, Presti S: Molecular analysis of cerebrospinal fluid: potential for the study of HIV-I infection of central nervous system. I Neurovirol 2000, 6 Suppl I():S95-SI 02.

35. Gisslen M, Svennerholm B, Norkrans G, Franzen C, Sall C, Svensson $\mathrm{R}$, Oberg S, Hagberg L: Cerebrospinal fluid and plasma viral load in HIV-I infected patients with various anti-retroviral treatment regiments. Scand J Infect Dis 2000, 32(4):365-369.

36. Garcia F, Niebla G, Romeu J, Vidal C, Plana M, Ortega M, Ruiz L, Gallart T, Clotet B, Miro JM, Pumarola T, Gatell JM: Cerebrospinal fluid HIV-I RNA levels in asymptomatic patients with early stage chronic HIV-I infection: support for the hypothesis of local virus replication. AIDS I999, I3( I 2): |49|- | 496.

37. Giancola ML, Uccella I, Alba L, Lorenzini P, Soldani F, Capobianchi M, Ruco L, Perno CF, Antinori A: HIV type I replication in cerebrospinal fluid of patients with AIDS-related non-Hodgkin's lym- 
phoma receiving chemotherapy and antiretroviral therapy. AIDS Res Hum Retroviruses 2003, 12:1091-1095.

38. Lafeuillade A, Poggi C, Pellegrino P, Corti K, Profizi N, Sayada C: HIVI replication in the plasma and cerebrospinal fluid. Infection 1996, 24:367-37I.

39. Burger DM, Boucher CA, Meenhorst PL, Kraayeveld CL, Portegies P, Mulder JW, Hoetelmans RM, Beijnen JH: HIV-I RNA levels in the cerebrospinal fluid may increase owing to damage to the blood-brain barrier. Antiviral Therapy 1997, 2:113-117.

40. De Luca A, Ciancio BC, Larussa D, Murri R, Cingolani A, Rizzo MG, Giancola ML, Ammassari A, Ortona L: Correlates of independent HIV-I replication in the CNS and of its control by retrovirals. Neurology 2002, 59:342-347.

4I. Enting RH, Prins JM, Jurriaans S, Brinkman K, Portegies P, Lange JMA: Concentrations of human immunodeficiency virus type I (HIV-I) RNA in cerebrospinal fluid antiretroviral treatment initiated during primary HIV-I infection. Clin Infects Dis 200I, 32:1095-1099.

42. Spudich SS, Nilsson AC, Lollo ND, Liegler TJ, Petropoulos CJ, Deeks SG, Paxinos EE, Price RW: Cerebrospinal fluid HIV infection and pleocytosis: Relation to systemic infection and antiretroviral treatment. BMC Infec Dis 2005, 5:98.

43. Sperber K, Shao L: Neurological consequences of HIV infection in the era of HAART. AIDS Patient Care STDS 2003, 17:509-5I8.

\section{Pre-publication history}

The pre-publication history for this paper can be accessed here:

http://www.biomedcentral.com/1471-2334/7/147/pre pub

Publish with Bio Med Central and every scientist can read your work free of charge

"BioMed Central will be the most significant development for disseminating the results of biomedical research in our lifetime. "

Sir Paul Nurse, Cancer Research UK

Your research papers will be:

- available free of charge to the entire biomedical community

- peer reviewed and published immediately upon acceptance

- cited in PubMed and archived on PubMed Central

- yours - you keep the copyright 